\title{
PEMILIHAN SUPPLIER GULA DENGAN PENDEKATAN FUZZY AHP PADA UD. AGUNG JAYA DI KECAMATAN BUNGAH GRESIK
}

\author{
Ahmad Bagus Zunaidi ${ }^{1}$, Said Salim Dahdah ${ }^{2}$, Dzakiyah Widyaningrum ${ }^{3}$ \\ ${ }^{1}$ Mahasiswa Teknik Industri, Fakultas Teknik, Universitas Muhammadiyah Gresik \\ ${ }^{2,3}$ Dosen Teknik Industri, Fakultas Teknik, Universitas Muhammadiyah Gresik Jl. Sumatera No. 101 \\ GKB-Gresik 61121, Jawa Timur, Indonesia \\ Email : baguszunaidi22@gmail.com
}

\begin{abstract}
ABSTRAK
UD. Agung Jaya merupakan salah satu unit usaha yang memproduksi petis udang. UD. Agung Jaya memproduksi 3 macam petis udang, yaitu petis udang grade A, B, dan C. Dalam pembuatan berbagai grade petis tersebut tentunya dibutuhkan bahan baku. Bahan baku petis udang antara lain: gula, tepung terigu, tepung ketan, sari udang, dan MSG. Penelitian ini melibatkan lebih dari satu kriteria dalam menentukan supplier, agar dapat membuat keputusan yang tepat maka diperlukan metode Multi Criteria Decision Making (MCDM). Metode yang digunakan disini adalah metode Analytical Hierarchy Process (AHP) dan Fuzzy Set, yang untuk selanjutnya disebut dengan metode Fuzzy Analytical Hierarchy Process (FAHP). Metode FAHP ini digunakan untuk mengatasi keterbatasan yang ada pada metode Analytical Hierarchy Process (AHP) yaitu ketidakmampuan dalam mempertimbangkan ketidakpastian yang muncul akibat subjektivitas manusia.

Hasil penelitian menunjukkan bahwa terdapat 3 kriteria yang harus dipertimbangkan dalam menentukan supplier di UD. Agung Jaya. Ketiga kriteria tersebut adalah harga, kualitas, dan pengiriman. Hasil dari tahapan metode Fuzzy Analytical Hierarchy Process (FAHP) didapatkan urutan supplier sebagai berikut : BNP 154,18 diperoleh untuk supplier 3, BNP 148,09 untuk supplier 1 dan BNP 147,85 untuk supplier 2

Kata kunci : Supplier, kriteria pemilihan supplier, perbandingan berpasangan, Fuzzy Analytical Hierarchy
\end{abstract} Process (FAHP).

\section{PENDAHULUAN}

Di era globalisasi seperti saat ini, persaingan antar perusahaan menjadi semakin ketat. Konsumen tidak lagi hanya menginginkan produk yang berkualitas, melainkan juga menuntut pelayanan yang baik dan tepat waktu. Supplier sebagai pihak penyedia bahan baku, sangat berperan penting dalam menentukan kualitas produk dan kelancaran proses produksi. Untuk itu, perusahaan perlu selektif dalam memilih supplier sebagai mitra bisnis.

UD. Agung Jaya merupakan salah satu unit usaha yang memproduksi petis udang. UD. Agung Jaya memproduksi 3 macam petis udang, yaitu petis udang grade A, B, dan C. Dalam pembuatan berbagai grade petis tersebut tentunya dibutuhkan bahan baku. Bahan baku petis udang antara lain: gula, tepung terigu, tepung ketan, sari udang, dan MSG. Kebutuhan bahan baku UD.Agung jaya setiap bulannya dapat dilihat pada tabel 1.1
Tabel 1.1 Kebutuhan dan Terkirimnya Bahan Baku

\begin{tabular}{|c|c|c|c|c|c|c|c|c|c|c|}
\hline Bulan & $\begin{array}{l}\text { Rebuthinan } \\
\text { Gulla }\end{array}$ & Terkirim & $\begin{array}{c}\text { Kebutuhanan } \\
\text { Sari } \\
\text { Vdange }\end{array}$ & Teklinim & $\begin{array}{l}\text { Relouthanan } \\
\text { Garam }\end{array}$ & Terlarim & $\begin{array}{l}\text { Relouthanan } \\
\text { Teppumg } \\
\text { Retan }\end{array}$ & Tellarim & $\begin{array}{c}\text { Revoutuha } \\
\text { nTepung } \\
\text { Tenigu }\end{array}$ & Tethim \\
\hline Jamari & 7000 & 5000 & 11200 & 11200 & 140 & 140 & 700 & 600 & 700 & 700 \\
\hline Feturari & 7000 & 7000 & 11200 & 11200 & 140 & 140 & 700 & 700 & 700 & 700 \\
\hline Maret & 7000 & 6500 & 11200 & 11200 & 140 & 100 & 700 & 600 & 700 & 600 \\
\hline Apri & 7000 & 6000 & 111200 & 11200 & 140 & 140 & 700 & 700 & 700 & 650 \\
\hline Mei & 7000 & 5000 & 11200 & 111000 & 140 & 100 & 700 & 650 & 700 & 700 \\
\hline Jumi & 7000 & 7000 & 11200 & 11200 & 140 & 120 & 700 & 600 & 700 & 700 \\
\hline IJli & 7000 & 7000 & 11200 & 11200 & 140 & 100 & 700 & 700 & 700 & 600 \\
\hline Agustus & 7000 & 5500 & 11200 & 11200 & 140 & 140 & 700 & 700 & 700 & 700 \\
\hline September & 7000 & 6500 & 11200 & 10000 & 140 & 140 & 700 & 700 & 700 & 700 \\
\hline Oltober & 7000 & 6000 & 11200 & 11200 & 140 & 140 & 700 & 600 & 700 & 600 \\
\hline Noverember & 7000 & 7000 & 111200 & 11200 & 140 & 140 & 700 & 700 & 700 & 650 \\
\hline Desember & 7000 & 6500 & 11200 & 11200 & 140 & 100 & 700 & 700 & 700 & 700 \\
\hline
\end{tabular}

Dari data kebutuhan diatas dapat dilihat kebutuhan bahan bakunya lebih besar di bandingkan dari bahan baku yang di kirim oleh sebab itu terjadi keterlambatan bahan baku.

\subsection{Perumusan Masalah}

Adapun rumusan masalah pada penelitian ini adalah sebagai berikut:

1. Kriteria apa yang menjadi prioritas 
dalam proses pemilihan supplier terbaik di UD. Agung Jaya?

2. Bagaimana menentukan supplier bahan baku gula yang terbaik untuk UD. Agung Jaya?

\subsection{Tujuan Penelitian}

Adapun tujuan penelitian ini adalah sebagai berikut:

1. Mengidentifikasi kriteria yang menjadi prioritas dalam pemilihan supplier bahan baku gula pada UD. Agung Jaya.

2. Menentukan supplier yang memiliki performansi terbaik dalam memasok bahan baku gula pada UD. Agung Jaya.

\subsection{Manfaat Penelitian}

Adapun manfaat penelitian ini adalah sebagai berikut:

Dapat mengetahui kriteria yang menjadi prioritas dalam pemilihan supplier bahan baku gula.

1. Dapat mengetahui supplier yang memiliki performansi terbaik dalam memasok bahan baku gula.

\subsection{Batasan Masalah}

Adapun batasan masalah dari penelitian ini adalah

1. Pembobotan nilai dari supplier dilakukan oleh karyawan UD. Agung Jaya yaitu bagian keuangan, bagian pemasaran, dan bagian produksi.

\subsection{Asumsi-asumsi}

Adapun asumsi pada penelitian ini adalah sebagai berikut:

1. Responden mengetahui bahan baku yang diinginkan oleh perusahaan (bahan baku gula yang dimaksud yaitu gula lokal) 


\section{Tinjauan Pustaka}

\subsection{Analytical Hierarchy Prosess (AHP)}

Menurut Afrianty (2011), Analytical Hierarchy Process (AHP) merupakan suatu model pendukung keputusan yang Logika fuzzy diperkenalkan pertama dikembangkan oleh Thomas L. Saaty. Pada hakikatnya AHP memperhitungkan hal-hal yang bersifat kuantitatif dan kualitatif. Konsepnya yaitu merubah nilai-nilai kualitatif menjadi kuantitatif, sehingga keputusan yang diambil bisa lebih objektif.

Menurut Noviandri, dkk AHP merupakan metode yang digunakan dalam proses pengambilan keputusan suatu masalah kompleks seperti perencanaan, penentuan alternatif, penyusunan prioritas, pemilihan kebijaksaan, alokasi sumber, penentuan kebutuhan, peramalan kebutuhan, perencanaan performansi, optimasi, dan pemecahan konflik. Sedangkan menurut Shega, Rahmawati, Yasin (2012) AHP digunakan untuk mengkaji permasalahan yang dimulai dengan mendifinisikan permasalahan tersebut secra seksama kemudian menyusunnya ke dalam suatu hierarki. AHP memasukkan pertimbangan dan nilai-nilai pribadi secara logis. Proses ini bergantung pada imajinasi, pengalaman, dan pengetahuan untuk menyusun hirarki suatu permasalahan dan bergantung pada logika dan pengalaman untuk memberi pertimbangan.

Teori Fuzzy kali oleh prof, lotfi A,zadeh berpendapat bahwa nilai benar dan salah dalam logika konvesional tidak mampu mengatasi masalah gradasi yang tidak terhingga pada dunia nyata.untuk mengatasi permasalahan tersebut, zadeh kemudian mengembangkan teori himpunan fuuzy, tidak seperti logika boolean yang hanya memiliki dua nilai yaitu benar atau salah,logika fuzzy mempunyai nilai yang kontinu, benar atauatau salah logika fuzzy tidak mutlak,tergantung dari derajat keanggotaan yang dumilikinya yaitu dalam rentang 0 hingga 1 , sehingga pada waktu yang bersamaan suatu keadaan dapat dikatakan sebagai benar dan salah. Maka dari itu peranan derajat keanggotaan sangatlah penting dan menjadi ciri khas dari fuzzy.

Menurut Sonalitha, Sarosa, Naba (2015), Logika fuzzy merupakan sebuah logika yang memiliki nilai kekaburan atau kesamaan (fuzzyness) anatara dua nilai. Teori fuzzy pertama dikemukakan oleh Lotfi A. Zadeh pada tahun 1965. Nilai tidak pasti atau tidak tepat, biasanya penilaian dilakukan menggunakna nilainilai lingustik seperti "tinggi", "rendah", "baik", "menengah", dll, untuk mengambarkan hal tersebut.

Pengertian FAHPJ|F-AHP merupakan gabungan metode AHP dengan pendekatan konsep Fuzzy. F- AHP menutupi kelemahan yang terdapat pada AHP, yaitu permasalahan terhadap kriteria yang memiliki sifat subjektif lebih banyak. Ketidakpastian bilangan direpresentasikan dengan uruta skala.(Muhamad fajri'2018).

\subsection{Prinsip Kerja AHP}

Menurut Afrianty (2011) prinsip kerja AHP adalah menguraikan masalah multi faktor atau multi kriteria yang kompleks menjadi suatu hirarki. Hirarki didefinisikan sebagai suatu representasi dari sebuah permasalahan kompleks dalam suatu struktur multi level dimana level pertama adalah tujuan, yang diikuti level faktor, kriteria, sub kriteria, dan seterusnya ke bawah hingga level terakhir dari alternatif. Kemudian tingkat kepentingan setiap variabel diberi nilai numerik secara subjektif tentang arti penting variabel tersebut secara relatif dibandingkan dengan variabel lain.Analytical Hierarchy Prosess (AHP) adalah suatu teori tentang pengukuran yang digunakan untuk menemukan skala rasio dengan melakukan perbandingan 
berpasangan antar faktor (Sonalitha, Sarosa, Naba, 2015).

Menurut Shega, Rahmawati, Yasin (2012), Hirarki adalah gambaran dari permasalahan yang kompleks dalam struktur banyak tingkat dimana tingkat paling atas adalah tujuan dan diikuti tingkat kriteria, subkriteria dan seterusnya ke bawah sampai pada tingkat yang paling bawah adalah tingkat alternatif. Hirarki menggambarkan secara grafis saling ketergantungan elemenelemen yang relevan, memperlihatkan hubungan antar elemen yang homogen dan hubungan dengan sistem sehingga menjadi satu kesatuan yang utuh. Struktur AHP ditunjukkan seperti pada Gambar 2

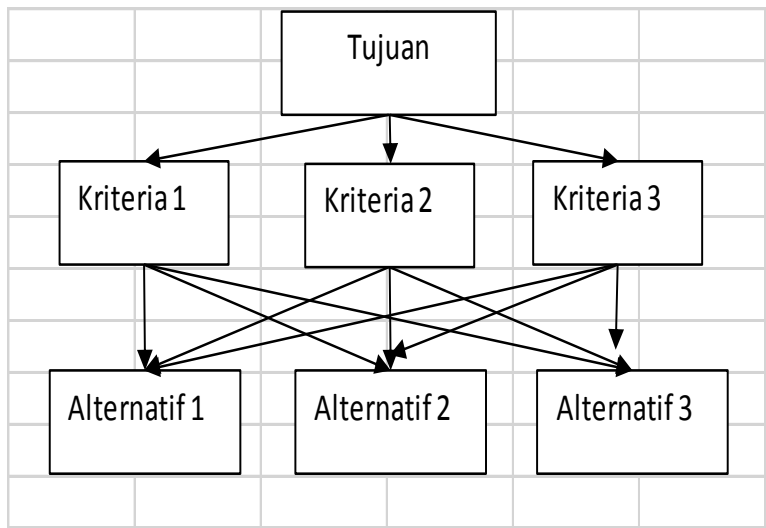

Gambar 2.1. Hirarki model AHP

\subsection{Pengertian FAHP}

F-AHP merupakan gabungan metode AHP dengan pendekatan konsep Fuzzy. F-AHP menutupi kelemahan yang terdapat pada AHP, yaitu permasalahan terhadap kriteria yang memiliki sifat subjektif lebih banyak. Ketidakpastian bilangan direpresentasikan dengan uruta skala.(Muhamad fajri'2018).

\section{Fuzzy Analytical Hierarchy}

Proces (F-AHP)yaitu merupakan metode analitik yang di kembangkan dari metode AHP dengan menggunakan pendekatan fuzzy. Metode ini di kembangkan untuk memperbaiki kelemahan yang ada pada metode AHP, yaitu untuk mengatasi ketidakmampuan metode AHP dalam memberikan penilaian yang presisi pada matriks perbandingan berpasangan
(Hakan et al., 2015). Perbedaan metode ini dengan metode AHP terletak pada implementasi penilaian dalam matriks perbandingan berpasangan antara kriteria, di mana pada F-AHP nilai setia kriteria diwakili oleh tiga variabel $(a, b, c)$ atau 1,m,u yang disebut Triangular Fuzzy Number (TFN). (Fernando parulian saputra 2018).

$$
\text { Menurut Ahmad Faisol }
$$

(2015), Metode Fuzzy Analytical Hierarchy Process (FAHP) pertama kali diusulkan oleh seorang peneliti bernama Chang dan merupakan perpanjangan langsung dari metode AHP yang diciptakan oleh Saaty yang terdiri dari unsur-unsur matriks yang diwakili oleh bilangan fuzzy.

Metode FAHP menggunakan rasio fuzzy yang disebut Triangular Fuzzy Number (TFN) dan digunakan dalam proses fuzzifikasi TFN terdiri dari tiga fungsi keanggotaan yaitu nilai terendah ( 1 ), nilai tenga ( $\mathrm{m}$ ), dan nilai tertinggi ( $\mathrm{u}$ ).

\subsection{Langka-Langka F-AHP}

Berikut ini adalah langkah-

langkah Fuzzy Analitical Process Hierarki $(F-A H P)$ yang dirumuskan oleh Chow Yang, (Juwita, 2010):

\section{Decomposition \\ 2. Matrix Comparison \\ 3. Menghitung Nilai Concistency Ratio}

Thomas L. Saaty telah membuktikan bahwa indeks konsistensi dari matriks berordo $n$ dapat diperoleh dengan rumus sebagai berikut:

$$
\begin{aligned}
& \mathrm{CI}=\left(\lambda_{\max }-\mathrm{n}\right) \\
& (\mathrm{n}-1) \\
& \mathrm{CI}=\text { Rasio penyimpangan } \\
& \text { (deviasi) konsistensi } \\
& \text { nsistency indeks) } \\
& \lambda_{\max }=\text { Nilai terbesar dari } \\
& \text { matriks berordo } n \\
& \mathrm{n} \quad=\text { ordo matriks } \\
& \text { Apabila CI bernilai nol, } \\
& \text { maka matriks pair wise } \\
& \text { comparison tersebut }
\end{aligned}
$$


konsisten.

4. Mengkonversi PCM dalam skala bilangan menjadi PCM skala fuzzy Setelah didapatkan PCM dalam skala bilangan, kemudian skala bilangan tersebut dikonversikan ke dalam bentuk skala fuzzy yang didefinisikan oleh tiga parameter TFN seperti pada table 2.1

Tabel 2.1 Skala AHP dan Triangular Fuzzy Number

\section{Tabel Skalah AHP dan Triangular Fuzzy Number}

\begin{tabular}{|c|c|c|c|}
\hline Skala AHP & Skala Fuzzy & $\begin{array}{c}\text { Invers skala } \\
\text { Fuzzy }\end{array}$ & Keterangan \\
\hline 1 & $1,1,1$ & $1,1,1$ & Sama penting \\
\hline 3 & $2,3,4$ & $\frac{1}{4}, \frac{1}{3}, \frac{1}{2}$ & Sedikit lebih penting \\
\hline 4 & $3,4,5$ & $\frac{1}{5}, \frac{1}{4}, \frac{1}{3}$ & $\begin{array}{c}\text { Skala antara sedikit lebih } \\
\text { dan lebih penting }\end{array}$ \\
\hline 5 & $4,5,6$ & $\frac{1}{6}, \frac{1}{5}, \frac{1}{4}$ & Lebih penting \\
\hline 6 & $5,6,7$ & $\frac{1}{7}, \frac{1}{6}, \frac{1}{5}$ & $\begin{array}{c}\text { Skala antara lebih dan } \\
\text { sangat penting }\end{array}$ \\
\hline 7 & $6,7,8$ & $\frac{1}{8}, \frac{1}{7}, \frac{1}{6}$ & Sangat penting \\
\hline 8 & $7,8,9$ & $\frac{1}{9}, \frac{1}{8}, \frac{1}{7}$ & $\begin{array}{c}\text { Skala antara sangat dan } \\
\text { mutlak lebih penting }\end{array}$ \\
\hline 9 & $8,9,9$ & $\frac{1}{9}, \frac{1}{9}, \frac{1}{8}$ & Mutlak lebih penting \\
\hline
\end{tabular}

Sumber Hsu,et al 2010

5.Menghitung elemen matriks Synthetic Pairwise Comparison

6.Bobot fuzzy

$$
\tilde{\mathrm{a}}_{i j}=\left(a_{i j}^{1} \times a_{i j}^{2} \times \ldots \times a_{i j}^{n}\right)^{1 / \mathrm{n}}
$$

Mendefinisikanrata-ratageometris

fuzzy dan bobot fuzzy setiap kriteriadengan rata-rata menggunakan metodaBuckley (1985) sebagaiberikut:

$$
\begin{aligned}
& \mathrm{r}=\left(\mathrm{a}_{\mathrm{i} 1} \times \mathrm{a}_{\mathrm{i} 2} \times \ldots \times \mathrm{a}_{\mathrm{in}}\right)^{1 / \mathrm{n}} \\
& \mathrm{w}=\mathrm{r}_{\mathrm{i}} \times\left(\mathrm{r}_{1}+\mathrm{r}_{2}+\ldots+\mathrm{r}_{\mathrm{n}}\right)^{-1}
\end{aligned}
$$

Dimana nilai syntheticpairwisecomparisonfuzzy dari kriteria $I$ terhadap kriteria $n, r_{\mathrm{i}}$ adalah rata-rata geometrikdari nilai perbandingan fuzzy kriteria $I$ terhadap setiap kriteria,dan $w_{\mathrm{i}}$ adalah bobot fuzzy dari kriteria ke $-i, n$ adalah jumlah kriteria yang dibandingkan dan dapat diindikasikan dengan TFN $w_{\mathrm{i}}=$ $\left(l w_{\mathrm{i}}, m w_{\mathrm{i}}, u w_{\mathrm{i}}\right), l w_{\mathrm{i}}$ adalah nilai terendah, $m w_{\mathrm{i}}$ adalah nilai tengah, $u w_{\mathrm{i}}$ adalah nilai tertinggi dari bobot fuzzy kriteria ke-i.

\section{Alternative Assesment}

Mengukur variabel linguistik untuk menunjukkan performansi kriteria dengan ungkapan "sangat baik", "baik", "cukup", "kurang", dan "sangat kurang" yang merupakan penilaian subyektif dari evaluator. Setiap variabel linguistik diindikasikan dengan TFN dalam skala 0 - 100. Evaluator bisa menetapkan skala variabel linguistiknya berdasarkan subyektifitasnya yang dapat mengindikasikan fungsi keanggotaan nilai yang dinyatakan oleh masingmasing evaluator. Jika $\mathrm{E}_{\mathrm{ij}}^{\mathrm{k}}$ adalah nilai performansi fuzzy dari evaluator $\mathrm{k}$ terhadap alternatif i pada kriteria j maka kriteria evaluasinya dinyatakan dalam

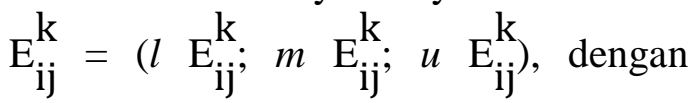
evaluator maka integrasi nilai keputusan fuzzy-nya adalah:

$E_{i j}=(1 / n) x\left(E_{i j}^{1}+E_{i j}^{2}+\ldots . .+E_{i j}^{n}\right)$ dimana $E_{i j}$ menunjukkan rata-rata nilai fuzzy dari penilaian pengambilan keputusan yang dapat dinyatakan dengan TFN sebagai $\mathrm{E}_{\mathrm{ij}}=\left(l \mathrm{E}_{\mathrm{ij}} ; m \mathrm{E}_{\mathrm{ij}}\right.$; $u \mathrm{E}_{\mathrm{ij}}$ ) yang masing - masing nilainya dapat dicari sebagai beriku

$$
\begin{array}{ll}
l \mathrm{E}_{\mathrm{ij}} & =\left(\sum_{k-1}^{m} l E_{i j}^{k}\right) / \mathrm{n} \\
m \mathrm{E}_{\mathrm{ij}} & =\left(\sum_{k-1}^{m} m E_{i j}^{k}\right) / \mathrm{n} \\
u \mathrm{E}_{\mathrm{ij}} & =\left(\sum_{k-1}^{m} u E_{i j}^{k}\right) / \mathrm{n}
\end{array}
$$

\section{Fuzzy Synthetic Decision}

Bobot setiap kriteria dan nilai performansi fuzzy harus diintegrasikan dengan perhitungan bilangan fuzzy. Berdasarkan bobot setiap kriteria $w_{\mathrm{j}}$ yang diperoleh dari pembobotan fuzzy dan matriks performansi fuzzy dapat diperoleh dari matriks fuzzy Synthetic Decision sebagai berikut $\mathrm{R}=\mathrm{E} * w$. pendekatan nilai fuzzy $R_{i}$ terwakili oleh

$$
\mathrm{R}_{\mathrm{i}}=\left(l \mathrm{R}_{\mathrm{i}} ; m \mathrm{R}_{\mathrm{i}} ; u \mathrm{R}_{\mathrm{i}}\right) \text {, dimana }
$$

$$
\begin{aligned}
& l \mathrm{R}=\sum_{j-i}^{n} l E_{\mathrm{ij}} \times l w_{j}, \\
& m \mathrm{R}=\sum_{j-i}^{n} m E_{\mathrm{ij}} \times m w_{j}, \\
& u \mathrm{R}=\sum_{j-i}^{n} u E_{\mathrm{ij}} \times u w_{j} .
\end{aligned}
$$




\section{Fuzzy Rangking}

Hasil Fuzzy Synthetic Decision yang dicapai oleh setiap alternatif merupakan bilangan fuzzy. Oleh karena itu diperlukan metode pe-rangking-an nonfuzzy pada bilangan fuzzy yang diterapkan pada perbandingan setiap alternatif. Dengan kata lain prosedur defuzzy-fikasi untuk mendapatkan Nonfuzzy performance (BNP). Ada banyak metode de-fuzzy-fikasi, namun metode center of area (COA) merupakan metode yang simpel dan sederhana. Nilai BNP dari bilangan fuzzy $i \quad R \%$ dapat diperoleh dengan persamaan berikut: $B N P i=[(u R i-l R i)+(m R i-l R i)] / 3$ Perankingan setiap alternatif dilakukan berdasarkan BNP dari setiap alternatif. BNP yang paling tinggi merupakan nilai performanci tertinggi.

\section{METODE PENELITIAN}

Penelitian adalah pekerjaan ilmiah yang bermaksud mengungkapkan rahasia ilmu secara objektif dengan disertai buktibukti yang lengkap dan kokoh. Metode adalah ilmu-ilmu yang digunakan untuk memperoleh kebenaran menggunakan penelusuran dengan tata cara yang lebih terperinci mengenai tahap-tahap melakukan sebuah penelitian.

\section{Flowchart Penyelesaian Masalah}

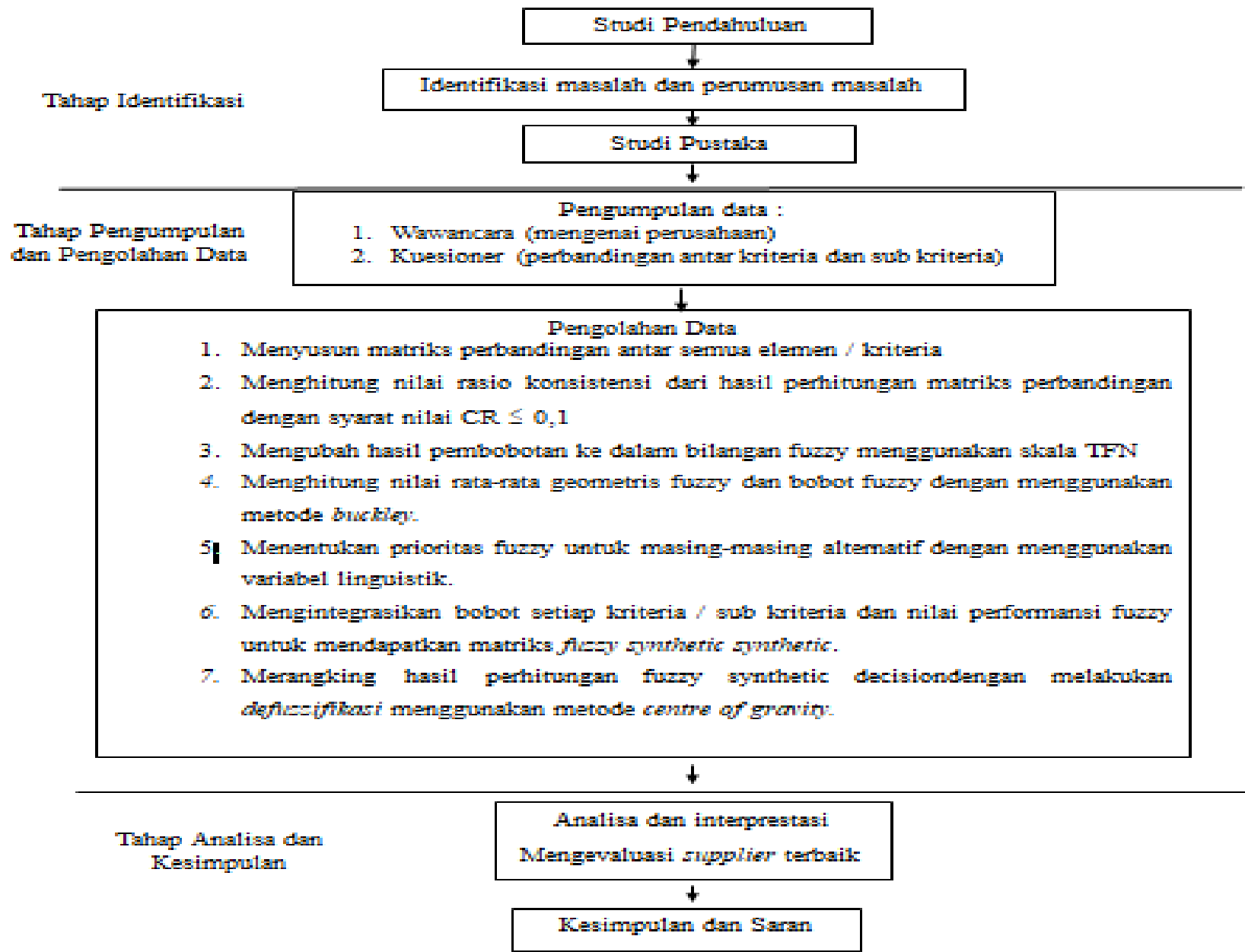

Gambar 3.1 Flowchart Metode Penelitian 


\section{Hasil dan Analisis}

Penentuan kriteria dan sub kriteria untuk menentukan pemilihan supplier terbaik pada UD. Agung Jaya, berdasarkan referensi jurnal (Sulistiana dan Yuliawati, 2012) yang sesuai dengan keadaan perusahaan, adapun kriteria dan sub kriteria yang digunakan adalah sebagai berikut :

1. Harga $(\mathrm{H})$ Memiliki 3 sub kriteria yaitu:

a. Kesesuaian Harga (KH)

Kriteria kesesuaian harga merupakan kriteria menilai tingkat keekonomisan pembelian dari suatu supplier.

b. Ketentuan Pembayaran (KP)

Kriteria ketentuan pembayaran merupakan penilaian dari ketentuan pembayaran yang diberikan dari supplier.

c. Persentase Diskon (PD)

Kriteria presentase diskon merupakan kriteria yang menilai seberapa besar diskon yang diberikan dari supplier.

2. Kualitas (K) memiliki 3 sub kriteria yaitu:

a. Warna Gula (W)

Kriteria warna gula yaitu menilai seberapa warna gula tersebut sesuai dengan apa yang diharapkan oleh perusahaan.

b. Testur Gula (T)

Kriteria tekstur gula yaitu menilai tekstur gula yang diharapkan perusahaan agar produk yang dihasilkan baik.

c. Rasa Gula (R)

Kriteria rasa gula yaitu menilai rasa gula yang diharapkan oleh perusahaan.

3. Pengiriman barang $(\mathrm{P})$ memiliki 3 sub kriteria yaitu:

a. Ketetapan Waktu Pengiriman (KW)

Kriteria ketetapan pengiriman merupakan penilaian pengiriman produk dari supplier yang sesuai dengan keinginan perusahaan. b. Ketetapan Jumlah Pengiriman (KJP)

Kriteria ketetapan jumlah pengiriman yaitu penilaian ketepatan jumlah dari pengiriman produk dari supplier.

c. Kontinuitas Pengiriman (KP)

Kriteria kontinuitas pengiriman merupakan penilaian kontinuitas produk dalam pengiriman produk dari supplier

\subsection{Hasil Dari Kuisioner}

1. Menyusun Matriks Perbandingan Berpasangan Antar Kriteria

Tabel 4.1Rekapitulasi Hasil Kuesioner Antar Kriteria

\begin{tabular}{|c|c|c|c|}
\hline & $\mathrm{H}$ & $\mathrm{K}$ & $\mathrm{P}$ \\
\hline $\mathrm{H}$ & 1,00 & 3,00 & 5,00 \\
\hline $\mathrm{K}$ & 0,33 & 1,00 & 3,00 \\
\hline $\mathrm{P}$ & 0,20 & 0,33 & 1,00 \\
\hline$\Sigma$ & 1,53 & 4,33 & 9,00 \\
\hline \multicolumn{4}{|c|}{$\begin{array}{l}\text { Menghitung vektor prioritas untuk } \\
\text { antar kriteria }\end{array}$} \\
\hline
\end{tabular}

Tabel 4.2 Penjumlahan Baris dan Kolom

\begin{tabular}{|c|c|c|c|c|}
\hline & $\mathrm{H}$ & $\mathrm{K}$ & $\mathrm{P}$ & $\begin{array}{c}\text { total } \\
\text { baris }\end{array}$ \\
\hline $\mathrm{H}$ & 0,65 & 0,69 & 0,56 & 1,90 \\
\hline $\mathrm{K}$ & 0,22 & 0,23 & 0,33 & 0,78 \\
\hline $\mathrm{P}$ & 0,13 & 0,08 & 0,11 & 0,32 \\
\hline $\begin{array}{c}\text { Total } \\
\text { kolom }\end{array}$ & 1,00 & 1,00 & 1,00 & 3,00 \\
\hline
\end{tabular}

3. Fuzzyfikasi PCM (Parwise Matrix Comparasi)

4. Menyusun Matriks Perbandingan Berpasangan Harga

Tabel 4.3 Hasil Kuesioner Sub Kriteria Harga

\begin{tabular}{|c|c|c|c|}
\hline & KH & KP & PD \\
\hline KH & 1,00 & 2,00 & 3,00 \\
\hline KP & 0,50 & 1,00 & 4,00 \\
\hline PD & 0,33 & 0,25 & 1,00 \\
\hline
\end{tabular}

5. Menyusun Matriks Perbandingan Berpasangan Sub Kriteria Kualitas

Tabel 4.4 Hasil Kuesioner Sub Kriteria Kualitas

\begin{tabular}{|c|c|c|c|}
\hline & W & $T$ & $R$ \\
\hline W & 1,00 & 3,00 & 5,00 \\
\hline
\end{tabular}




\begin{tabular}{|c|c|c|c|}
$T$ & 0,33 & 1,00 & 3,00 \\
\hline$R$ & 0,20 & 0,33 & 1,00 \\
\hline$\Sigma$ & 1,53 & 4,33 & 9,00 \\
\hline
\end{tabular}

6. Menyusun Matriks Perbandingan

Berpasangan Sub Kriteria Pengiriman.

Tabel 4.5 Hasil Rekapitulasi Sub Kriteria Pengiriman

\begin{tabular}{|c|c|c|c|}
\hline & KW & KJP & KP \\
\hline KW & 1,00 & 2,00 & 5,00 \\
\hline$K J P$ & 0,50 & 1,00 & 4,00 \\
\hline$K P$ & 0,20 & 0,25 & 1,00 \\
\hline$\Sigma$ & 1,70 & 3,25 & 10,00 \\
\hline
\end{tabular}

7. Hasil perhitungan bobot $\mathrm{BNP}$

Tabel 4.6 Hasil Perhitungan Bobot BNP

Seluruh Kriteria Dan Sub Kriteria

\begin{tabular}{|c|c|c|c|c|c|c|c|}
\hline \multirow{2}{*}{$\begin{array}{c}\text { kriteria / } \\
\text { subkriteria }\end{array}$} & \multicolumn{3}{|c|}{ bobot lokal } & \multicolumn{3}{|c|}{ bobot keseluruhan } & \multirow[t]{2}{*}{ BNP } \\
\hline & $\mathrm{L}$ & M & $\mathrm{u}$ & $\mathrm{L}$ & M & $\mathrm{u}$ & \\
\hline Harga & 0,29 & 0,61 & 1,65 & & & & 0,85 \\
\hline 1. KH & 0,26 & 0,57 & 1,19 & 0,0754 & 0,3477 & 1,9635 & 0,8 \\
\hline 2. KP & 0,22 & 0,31 & 0,4 & 0,0638 & 0,1891 & 0,66 & 0,3 \\
\hline 3. PD & 0,09 & 0,11 & 0,13 & 0,0261 & 0,0671 & 0,2145 & 0,1 \\
\hline Kualitas & 0,21 & 0,29 & 0,55 & & & & 0,34 \\
\hline 1. $w$ & 0,29 & 0,61 & 1,2 & 0,08 & 0,18 & 0,44 & 0,23 \\
\hline 2. $\mathrm{T}$ & 0,21 & 0,29 & 0,38 & 0,03 & 0,07 & 0,19 & 0,09 \\
\hline 3. $\mathrm{R}$ & 0,09 & 0,13 & 0,12 & 0,02 & 0,04 & 0,11 & 0,06 \\
\hline pengiriman & 0,09 & 0,1 & 0,17 & & & & 0,12 \\
\hline 1. KW & 0,24 & 0,53 & 1,09 & 0,08 & 0,19 & 0,44 & 0,24 \\
\hline 2. KJP & 0,28 & 0,37 & 0,48 & 0,03 & 0,08 & 0,2 & 0,1 \\
\hline 3.KP & 0,09 & 0,09 & 0,11 & 0,01 & 0,03 & 0,08 & 0,04 \\
\hline
\end{tabular}

Tabel 4.7 Keseluruan Dari Fuzzy Synthetic

Decision

\begin{tabular}{|c|c|c|c|c|c|c|c|c|c|c|c|c|c|c|c|c|c|c|c|c|c|}
\hline \multirow[t]{2}{*}{ KRTBRAR } & \multicolumn{3}{|c|}{ BOOOTLOOALEKESEUNHAN } & \multicolumn{3}{|c|}{ 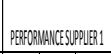 } & \multicolumn{3}{|c|}{ 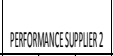 } & \multicolumn{3}{|c|}{ PEPROPNANCESLPPIIER3 } & \multicolumn{3}{|c|}{ RSPPVIR1 } & \multicolumn{3}{|c|}{ RSUPPIER? } & \multicolumn{3}{|c|}{ RSSPPIER3 } \\
\hline & 1 & m & u & I & m & 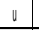 & 1 & m & U & I & m & U & 1 & m & 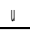 & I & m & & I & m & \\
\hline Evalanhagega & 0,08 & 0,35 & 1,60 & 61.7 & 73,33 & 76,6 & 61,6 & 66,6 & 7100 & 65,0 & 76,6 & 80 & 4,55 & 25,50 & 150,54 & 4,65 & 23,18 & 139,4 & 4,00 & 26,66 & \\
\hline Eetertuan pentar & 0,6 & 0,19 & 0,66 & $6.15650]$ & $\mid 6,65650]$ & $71,6066]$ & $60,3]$ & 80,0 & $8,3,3$ & 6833 & 0,008 & 83333 & 3,93 & 12,61 & 47,00 & 4,5 & 15,13 & 55,0 & 4,66 & 15,13 & 55, \\
\hline erentitze diston & 0,3 & 0,07 & 0,12 & 68,3333 & & 83,333 & 68,33 & 80,0 & $8,3,6$ & 68,33 & 0,0 & 83,33 & 1,78 & 5,37 & 1788 & 1,8 & 5,37 & 17,88 & 1,18 & 5,37 & 17 \\
\hline magla & 0,08 & 0,18 & 0,4 & 6,16606 & & $7,1,6560$ & 68,33 & 80,00 & 8,306 & 68,33 & 0,0 & 8833 & 4,93 & 12,00 & 32,63 & 5,47 & 14,0 & 36,67 & 5,47 & 14,0 & 30 \\
\hline estsugrala & 0,13 & 0,07 & 0,19 & 61,67 & 66,6] & 71,67 & 65,0 & 76,6 & 2000 & 6,67 & $6,6,6$ & 71,67 & 1.85 & 4,67 & 13,62 & 1,95 & 5,37] & 15,20 & 1,86 & 4,6] & 13. \\
\hline baggla & $0,0,2$ & 0,04 & 0,11 & 65 & 808 & $8,3,333$ & 68,33 & 80,0 & $8,3,3$ & 68,33 & 0,0 & 83,33 & 1,30 & 3,20 & 9,17 & 1.37 & 3,20 & 9,17 & 1,37 & 3,20 & \\
\hline Ketetapan waltury & 0,08 & 0,19 & O.4 & 683333 & 808 & 83,3333 & 61,0 & 66,6 & $71,6]$ & 61,67 & 66,67 & |1165650] & 5,47 & 15,20 & $36,6]$ & 4,93 & 12,67 & 31,53 & 4,98 & $12,6]$ & 31 \\
\hline 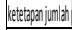 & 0,3 & 0,18 & 0,20 & 65 & T6,6650 & $\infty$ & 60,33 & 80,0 & 83,36 & 6833 & 0,0 & 83,33 & 1,95 & 6,13 & 15000 & 205 & 6,0 & 15,607 & 2,165 & 6,0 & 1 \\
\hline ntinutits pengin & 0,01 & 0,13 & 0,08 & 65 & $|6,66560|$ & $\infty$ & 60,33 & 80,0 & & 6833 & 0,0 & 83,33 & 0,55 & 2,30 & 6,40 & 0,68 & 2,40 & 6,67 & 0,68 & 240 & 6 \\
\hline \multicolumn{13}{|c|}{ Tota $\mathrm{R}$} & 26,52 & 87,5 & 30,19 & 27,24 & 88,11 & 388,18 & 2739 & & \\
\hline \multicolumn{13}{|c|}{ Defouz $\mathbb{N P}$} & \multicolumn{3}{|c|}{18919} & \multicolumn{3}{|c|}{197,55} & \multicolumn{3}{|c|}{154,18} \\
\hline \multicolumn{13}{|c|}{ Peinglat } & & 2 & & & 3 & & & 1 & \\
\hline
\end{tabular}

Berdasarkan pada tabel 4.53 dapat dilihat bahwa hasil BNP dari setiap supplier yaitu supplier 1 sebesar 148,09, supplier 2 sebesar 147,85, dan supplier 3sebesar 154,18 . Maka peringkat tertinggi dari ketiga supplier tersebut supplier 3.

\section{KESIMPULAN DAN SARAN \\ 5.1 Kesimpulan}

Berdasarkan hasil perhitungan, analisis dan pembahasan yang telah dilakukan, maka dapat dimbil kesimpulan sebagai berikut :

1. Dari hasil perhitungan kriteria - kriteria yang menjadi prioritas dalam proses pemilihan bahan baku gula di UD. Agung Jaya adalah kriteria harga dengan sub kriteria Kesesuain harga.

2. Berdasarkan hasil pembobotan yang dilakukan dengan metode Fuzzy Analytical Hierarcy Process (FAHP). Supplier 3 memiliki bobot prioritas terbesar yaitu sebesar 154,18 dibandingkan dengan supplier lainya, hal ini ditunjukkan dengan tingginya bobot supplier 3 dalam beberapa aspek kriteria seperti harga, kualitas, dan pengiriman barang.

\subsection{Saran}

Untuk penelitian selanjutnya, ada beberapa saran yang dapat dijadikan pertimbangan bagi perusahaan dan penelitian selanjutnya. Saran - saran yang dapat diberikan penulis adalah sebagai berikut :

1. Pengambilan keputusan harus lebih memperhatikan dan mempertimbangkan kriteria - kriteria untuk pemilihan supplier dengan pertimbangan yang lebih baik dan obyektif agar pemilihan supplier mendapat solusi yang optimal.

2. Penerapan metode AHP dan Fuzzy AHP pada kasus - kasus lain di perusahaan selain pemilihan pemasok. 


\section{DAFTAR PUSTAKA}

Shega, Hanien Nia H, Rahmawati, Rita, dan Yasin, Hasbi. 2012. Penentuan Faktor Prioritas Mahasiswa Dalam Memilih Telepon Seluler Dengan Fuzzy Ahp.

Fajri, Muhammad, Putri dan Rekyan Regasari Mardhi. 2018. Impelementasi Metode FAHP Dalam Penentuan Permintaan Di MAN 2 KOTA Serang.

Rif'an, Muhammad. 2014. Analisa Pemilihan Pemasok Sayuran Dengan Metode Anlytic Hierarchy Proces AHP FUZZY.

Sonalitha, Elta, Sarosa, Moechammad, dan Naba, Agus. 2015. Pemilihan Pemasok Bahan Mentah Pada Restoran Mengolahan Metode Fuzzy Analytical Hierarchy Process.

Sulistiana, Winda, dan Yuliawati, Evi. Analisis Pemilihan Supplier Bahan Baku Dengan Menggunakan Metode FAHP.

Utama, Ditdit Nugeraha. 2017. Sistem Penunjang Keputusan. (Penerbit: Garudhawaca, Yogyakarta).

Saaty, Thomas L. 1993. Pengambilan Keputusan Bagi Para Pemimpin. (Penerbit:Gramedia, Jakarta)

Santoso, Tri Santoso. 2013. Analisis Strategi Pemasaran Produk Kerajinan Sepatu Pada UKM Galaksi, Desa Ciapus, Ciomas.

Faisol, Ahmad, Muslim, M. Aziz, dan Suyono, Hadi. 2014. Komparasi Fuzzy AHP dengan AHP pada Sistem Pendukung Keputusan Investasi Properti. Jurnal EECCIS Vol. 8 No.2. 